\title{
Visual acuity and refraction by age for children of three different ethnic groups in Paraguay
}

\author{
Acuidade visual e refração por idade para crianças de três grupos étnicos diferentes no Paraguai \\ Marissa Janine Carter ${ }^{1}$, Van Charles lansingh², Gisela Schacht ${ }^{3}$, Miguel Río del Amo ${ }^{5}$, Miguel Scalamogna ${ }^{3}$, Thomas Douglas France ${ }^{4}$
}

\begin{abstract}
Purpose: To characterize refractive errors in Paraguayan children aged 5-16 years and investigate effect of age, gender, and ethnicity.

Methods: The study was conducted at 3 schools that catered to Mennonite, indigenous, and mixed race children. Children were examined for presenting visual acuity, autorefraction with and without cycloplegia, and retinoscopy. Data were analyzed for myopia and hyperopia (SE $\leq-1 \mathrm{D}$ or $-0.5 \mathrm{D}$ and $\geq 2 \mathrm{D}$ or $\geq 3 \mathrm{D}$ ) and astigmatism (cylinder $\geq 1 \mathrm{D}$ ). Spherical equivalent (SE) values were calculated from right eye cycloplegic autorefraction data and analyzed using general linear modelling.

Results: There were 190,118, and 168 children of Mennonite, indigenous and mixed race ethnicity, respectively. SE values between right/left eyes were nonsignificant. Mean visual acuity (VA) without correction was better for Mennonites compared to indigenous or mixed race children (right eyes: 0.031, 0.090, and 0.102 logMAR units, respectively; $\mathrm{P}<0.000001$ ). There were 2 cases of myopia in the Mennonite group (1.2\%) and 2 cases in the mixed race group (1.4\%) (SE $\leq-0.5 \mathrm{D})$. The prevalence of hyperopia (SE $\geq 2$ D) was $40.6 \%, 34.2 \%$, and $46.3 \%$ for Mennonite, indigenous and mixed race children. Corresponding astigmatism rates were $3.2 \%, 9.5 \%$, and $12.7 \%$. Females were slightly more hyperopic than males, and the $9-11$ years age group was the most hyperopic. Mennonite and mixed race children were more hyperopic than indigenous children.
\end{abstract}

Conclusions: Paraguayan children were remarkably hyperopic and relatively free of myopia. Differences with regard to gender, age, and ethnicity were small.

Keywords: Refractive error/ethnology; Myopia; Hyperopia; Astigmatism; Ethnicity and health; Visual acuity; Humans; Child; Adolescent; Paraguay

\begin{abstract}
RESUMO
Objetivo: Caracterizar os erros de refração em crianças paraguaias com idades entre 5 e 16 anos e investigar efeito da idade, gênero e etnia.

Métodos: $O$ estudo foi realizado em três escolas que atendiam crianças de etnia Menonita, indígena e mista. As crianças foram examinadas em relação à acuidade visual, autorrefração com e sem cicloplegia, e retinoscopia. Os dados foram analisados para correção de miopia e hipermetropia (EE $\leq-1$ D ou $-0,5 D$ e $\geq 2 D$ ou $\geq 3 D$ ) e astigmatismo (cilindro $\geq 1 \mathrm{D}$ ). Valores equivalentes esféricos (EE) foram calculados a partir dos dados de autorrefração cicloplegiada do ol ho direito e analisados por meio de modelagem linear geral.
\end{abstract}

Resultados: Foram avaliadas 190, 118 e 168 crianças de etnias Menonita, indígenae mista, respectivamente. Diferenças entre os valores de EE de olhos direitos e esquerdos não foram significantes. A acuidade visual (AV) sem correção foi melhor para Menonitas em relação às crianças da etnia indígena ou mista (olho direito: 0,031, 0,090 e 0,102 log MAR, respectivamente; $P<0,000001$ ). Houve 2 casos de miopia no grupo Menonita $(1,2 \%)$ e 2 casos no grupo de etnia mista (1,4\%) (SE $\leq-0,5 D)$. A prevalência de hipermetropia (SE $\geq 2$ D) foide 40,6\%, 34,2\% e 46,3\% para as etnias Menonita, indígena e mista. As taxas correspondentes de astigmatismo foram de 3,2\%, 9,5\% e 12,7\%. As mulheres foram ligeiramente mais hipermétropes do que os homens, e o grupo de 9 a 11 anos de idade foi a mais hipermétrope. Crianças da etnia Menonita e mista se mostraram mais hipermétropes do que as crianças indígenas.

Conclusões: As crianças paraquaias são notavelmentehipermétropes erelativamente livres de miopia. Diferenças com relação ao sexo, idade e etnia são pequenas.

Descritores: Erros de refração/etnologia; Miopia; Hiperopia; Astigmatismo; Origem étnica e saúde; Acuidade visual; Humanos; Criança; Adolescente; Paraguai

\section{INTRODUCTION}

The prevalence of refractive errors in school children worldwide varies considerably. For example, the prevalence of myopia is relatively low in the United States (U.S.) ${ }^{(1-4)}$ with a range of 4-19\% (depending on age and ethnicity), but much higher in Greece ${ }^{(5)}$ at 37\%, and highest of all in Taiwan ${ }^{(6,7)}$ with a range of $12-85 \%$, depending on age. In Latin America, a great variance has also been observed with a lower prevalence of myopia in Brazil (4-6\%), a higher prevalence in Chile (3-19\%), and a very high prevalence in Mexico (75\%)(8-10).

There are multifactorial reasons for these ranges. First, younger children are generally more hyperopic, while myopia prevalence increases as children age. Emmetropia at an early age seems to carry a higher risk of developing myopia, and parental history may influence its development in offspring ${ }^{(11,12)}$. Second, there is no universal agreement on the definition of myopia. The prevalence of myopia was calculated in Singapore as $30.7 \%$ or $45.8 \%$, depending on whether a spherical equivalent cut-off point of $-1.00 \mathrm{D}$ or $-0.25 \mathrm{D}$ was used ${ }^{(13)}$. Third, environmental conditions, such as being in a closed environment or increased work can have a profound impact. For example, the "epidemic" of myopia observed in Asia in recent decades could be due to children spending more time in high rise apartments, more intensive school work, and other stress factors ${ }^{(14-17)}$. Finally, ethnicity may also be associated with the genetic predisposition of myopia or refractive error ${ }^{(2-4,14,18)}$.

In Latin America, the role of ethnicity in refractive errors has been less explored. The goal of this study was to examine refractive errors
Submitted for publication: January 16, 2013

Accepted for publication: January 31, 2013

Study was carried out in Fundación Vision, Asuncion, Paraguay.

Strategic Solutions, Inc., Cody, WY.

International Agency for the Prevention of Blindness/VISION 2020, Buenos Aires, Argentina.

Fundación Vision, Asuncion, Paraguay.

Department of Ophthalmology and Visual Sciences, University of Wisconsin, Madison, WI.

Affiliation should be Fundacion Vision, Asuncion, Paraguay.
Funding: Preparation of this manuscript was funded by Fundacion Vision, ORBIS, and the International Agency for the Prevention of Blindness (IAPB).

Disclosure: M.J.Carter, employed by Strategic Solutions and is a paid consultant to ORBIS and the IAPB; V.C.Lansingh, employed by the IAPB; G.SchCHT, employed by Fundacion Vision; M.R. del Amo, None; M.Scalamogna, employed by Fundacion Vision; T.D.France, employed by the University of Wisconsin.

Correspondence address: Marissa Carter. Strategic Solutions, Inc. - 1143 Salsbury Ave - Cody - WY 82414 - USA - E-mail: mcarter@strategic-solutions-inc.com 
in Paraguayan school children of 3 ethnicities: Mennonite (White, of German extraction), indigenous (Macca Indians), and mixed race (of European and indigenous). This is first study looking at ethnicity and refractive error in Paraguay.

\section{METHODS}

The study was conducted during April and May 2005 in a boarding school for indigenous children in Asuncion, a rural Mennonite community school (the only such school in the geographic area with children ultimately of White, Germanic extraction), and a mixed race school in Asuncion. In each school, the study was conducted until all the children present had been examined over approximately a 2-day period by 2 third-year ophthalmology residents trained by an experienced ophthalmologist for a week (90\% agreement between the residents and ophthalmologist). Consent for the study was given by the parents of each child and the study was approved by the Fundacion Vision IRB. Patient anonymity was preserved. The study also adhered to the tenets of the Declaration of Helsinki in 1995 (as revised in Tokyo 2004).

Each child was examined for presenting visual acuity (VA; with available correction), autorefraction with and without cycloplegia, and retinoscopy (with cycloplegia) by the 2 residents. The autorefractor (Seiko GR-2100, Hiroshima, Japan) was calibrated to the manufacturer's specifications prior to each use. The VA examination employed a Snellen chart for 6 meters, followed by noncycloplegic refraction using the autorefractor. Cycloplegia was induced by 2 drops of cyclopentolate and after a 45-60-minute waiting period, each child was re-examined using the autorefractor and then retinoscopy. The following data were collected for right and left eyes, and recorded in Excel sheets (Microsoft Inc, Redmond, WA): presenting visual acuity (Snellen values), sphere, cylinder, and axis values (autorefraction with and without cycloplegia; retinoscopy with cycloplegia). After a pilot study that analyzed the different methods, autorefraction with cycloplegia was chosen as the method to study differences.

Spherical equivalent (SE) in D was calculated as sphere measurement + (0.5 x cylinder measurement).

\section{Statistical analysis}

The results were analyzed using PASW 19 (SPSS Inc., Chicago, IL). SE values were compared between right and left eyes using general linear modelling (essentially MANOVA) with ethnicity as the factor to determine if they were equivalent for analytical purposes.

VAs were converted into the following Snellen categories: 20/20 (or better) to 20/40; 20/40 to 20/60; 20/60 to 20/200; and worse than 20/200. The VAs for each ethnic group were compared using gamma and Kendall's tau b for right eyes.

The number of cases of myopia, hyperopia, and astigmatism in any eye was first determined using the following definitions: myopia, SE $\leq-1$ D; hyperopia, SE $\geq 3$ D; and astigmatism, cylinder $\geq 1 \mathrm{D}^{(19)}$. Myopia and hyperopia cases were also determined using the following additional definitions: myopia, SE $\leq-0.5 \mathrm{D}$; hyperopia, $\geq 2 \mathrm{D}$. The number of cases for each category of refractive error for the 3 groups was analyzed by chi square.

Because right SE data were non-normal, a logistic regression was conducted in which SE data were divided into hyperopic (relaxed definition of $\geq 2 D$ ) using ethnicity, gender, and age ( $\leq 8$ years, 9-11 years, and $\geq 12$ years) as factors using all data.

\section{RESULTS}

\section{Demographics}

There were 190, 118, and 168 children of Mennonite ( $\leq 8$ years: 74; $9-11$ years: $53 ; \geq 12$ years: 63 ), indigenous ( $\leq 8$ years: $36 ; 9-11$ years: $32 ; \geq 12$ years: 51 ), and mixed race ethnicity ( $\leq 8$ years: $34 ; 9-11$ years: $97 ; \geq 12$ years: 37$)$

\section{SPHeRICAL EQUivalent: RIGHT VERSUS LeFT EYES}

Although Box's M test showed significant violation of homogeneity of variance $(p<0.001)$, Levene's test was non-significant for both independent variables (SE for right and left eyes). Because Box's M is very sensitive to small violations of homoscedasticity, we determined that selection of right eye data for further analysis was reasonable based on the nonsignificant differences between right and left eyes regarding SE between ethnic groups. For the different ethnic groups, SE means were slightly higher for left eyes in 2 groups: Mennonite: mean right eye $\mathrm{SE}=1.84$, mean left eye $\mathrm{SE}=1.89$; indigenous: mean right eye $\mathrm{SE}=1.69$, mean left eye $\mathrm{SE}=1.68$; mixed race: mean right eye $\mathrm{SE}=1.76$, mean left eye $\mathrm{SE}=1.80$ ).

\section{Visual ACUITY}

Visual acuity without correction was similar between ethnic groups although the Mennonites had a significantly higher proportion of right eyes in the $20 / 20$ to $20 / 40$ Snellen VA category ( $98.4 \%$ vs. $94.0 \%$ for indigenous and mixed race ethnicities), $p=0.029$ (Table 1). There were no clear differences within age groups according to ethnicity.

\section{MYOPIA, HYPEROPIA, AND ASTIGMATISM}

There was 1 case of myopia in the Mennonite group (0.6\%) and 2 cases in the mixed race group (1.4\%). Relaxing the definition of myopia to SE $\leq-0.5$ D only added 1 case to the Mennonite group (1.2\%). Ten cases of hyperopia were observed in each of the Mennonite and mixed race groups (5.3\% and 5.9\%, respectively), but only 6 cases in the indigenous group (5.1\%) for the definition SE $\geq 3 D(P=0.944)$. Using a definition of hyperopia of $S E \geq 2 \mathrm{D}$, increased the number of cases: Mennonite: 69 (40.6\%); indigenous: 38 (34.2\%); and mixed race: 68 (46.3\%); $P=0.150$. However, while there only 6 cases of astigmatism identified in the Mennonite group (3.2\%), there were 16 and 15 cases, respectively, in the mixed race and indigenous groups $(9.5 \%$ and $12.7 \%$, respectively) $(P=0.006)$. The distribution of astigmatism cases showed that two-thirds of Mennonite children had unilateral astigmatism, while in indigenous and mixed race children, the proportion was lower (56\% and 33\%, respectively) (Table 2). The proportion of eyes with more severe astigmatism $(\geq 2.00 \mathrm{D})$ was slightly higher for Mennonite children compared to the other groups. Females had a higher prevalence of astigmatism than males (10.1\% versus $6.7 \%$ ), but this result was not significant.

\section{LOGISTIC REGRESSION}

In the final model, the -2 log likelihood was 143.2 and the Nagelkerke $R^{2}$ was 0.102 . Only age and gender were significant in the model (Table 3 ). Being younger, specifically $\leq 8$ years, increased the odds of being hyperopic (OR: 4.31). Being female also increased the odds (OR: 2.91). Ethnicity was not a significant variable in the model.

\section{DISCUSSION}

In this study of Paraguayan children of 3 different ethnicities, we noted some significant differences in refractive errors. Overall, presenting VA was slightly better for Mennonite children compared to the indigenous and mixed race children, although the difference was small. For all the groups, the prevalence of myopia was very low using a definition of $\leq-1.00 \mathrm{D}$. Even when the cut point was lowered to $-0.5 \mathrm{D}$, the overall prevalence of myopia was still only $0.9 \%$. Hyperopia was more common - low at $4 \%$ using the SE $\geq 3$ D definition - but much higher when using the less stringent moderate hyperopia definition of SE $\geq 2$ D (40.9\%).

Most studies, including those done in Brazil, Chile, and Mexico have found a much lower prevalence than our figure for moderate hyperopia ${ }^{(2,8-11)}$. Past studies of refractive errors in children in the U.S. have also looked at ethnicity ${ }^{(2,3)}$, but the most recent study, the Collaborative Longitudinal Evaluation of Ethnicity and Refractive Error 
Table 1. Distribution of visual acuity by ethnicity using right eye data. Data in parenthesis represent percentages

\begin{tabular}{lcccc}
\hline Ethnicity & $\begin{array}{c}\mathbf{2 0 / 2 0} \text { to } \\
\mathbf{2 0 / 4 0}\end{array}$ & $\begin{array}{c}\mathbf{2 0 / 4 0} \text { to } \\
\mathbf{2 0 / 6 0}\end{array}$ & $\begin{array}{c}\mathbf{2 0 / 6 0} \text { to } \\
\mathbf{2 0 / 1 0 0}\end{array}$ & $\mathbf{< 2 0 / 1 0 0}$ \\
\hline Mennonite & $185(98.4)$ & $0(0)$ & $1(0.5)$ & $2(1.1)$ \\
Indigenous & $110(94.0)$ & $4(3.4)$ & $1(0.9)$ & $2(1.7)$ \\
Mixed race & $159(94.0)$ & $2(1.2)$ & $3(1.8)$ & $5(3.0)$ \\
\hline
\end{tabular}

Table 2. Distribution of astigmatism by child (unilateral or bilateral) and spherical equivalent values (D) by eye

\begin{tabular}{lcccccc}
\hline Ethnicity & Unilateral & Bilateral & $\mathbf{1 . 0 0}$ & $\mathbf{1 . 2 5}-\mathbf{1 . 7 5}$ & $\mathbf{2 . 0 0 - 2 . 7 5}$ & $\mathbf{2 3 . 0 0}$ \\
\hline Mennonite & 4 & 2 & 0 & 3 & 3 & 1 \\
Indigenous & 9 & 7 & 7 & 12 & 2 & 4 \\
Mixed race & 5 & 10 & 7 & 8 & 6 & 2 \\
\hline
\end{tabular}

Table 3. Logistic regression showing odds ratios (OR) of significant variables for hyperopia (dependent variable)

\begin{tabular}{lccc}
\hline Variable & OR & $\mathbf{9 5 \%} \mathbf{C l}^{*}$ & $\mathbf{P}^{\dagger}$ \\
\hline Age (years) & & & 0.013 \\
$\leq 8$ & & & 0.270 \\
$9-11$ & 4.31 & $1.18-15.72$ & 0.963 \\
Gender $^{\S}$ & 1.04 & $0.227-4.73$ & 0.046 \\
\hline
\end{tabular}

${ }^{*} \mathrm{Cl}=$ confidence interval; ${ }^{+} \mathrm{P}=$ significance; ${ }^{\ddagger}=\geq 12$ years; ${ }^{\S}=$ male.

Study, is considered the largest and most diverse study ${ }^{(4)}$. New cases of myopia that developed in 4,556 school-aged children were observed from 1989 through 2009 and occurred in 16.4\% of the children. By ethnicity, $27.3 \%$ of Asians developed new cases of myopia, $21.4 \%$ of Hispanics, $14.5 \%$ of Native Americans, $13.9 \%$ of African-Americans, and $11 \%$ of Caucasians ${ }^{(4)}$.

This suggests that in our Paraguayan population, children are more hyperopic compared with other child populations, which explains why myopia is relatively uncommon. Authors of an investigation of indigenous people aged 12 to 59 years in the northwestern Amazon region of Brazil determined that only $2.7 \%$ of eyes had myopia of $-1.0 \mathrm{D}$ or more ${ }^{(18)}$. By comparison, Brazilians from the small city in which the study was performed had higher rates of myopia (6.4\% of eyes), and younger, slightly educated Brazilians had a myopia prevalence of $11.3 \%$ in their eyes. Although the authors of this study ascribed the myopic differences to illiteracy, which might be true in this instance, the children in our study were literate, which indicates that other factors are at work, such as genetics, low stress, non-intensive near work, and perhaps more exposure to the outside environment. While hyperopia appeared to be significantly different between the ethnic groups, logistic regression showed that this difference was primarily due to age. However, astigmatism was also significant lower in the Mennonite children. The prevalence of astigmatism in indigenous children was $12.7 \%$, similar to the level of astigmatism in the indigenous Amazon study (15.5\%)(18).

There were some refractive error differences by gender with females being more hyperopic than males. Females also had a higher prevalence of astigmatism, although it was nonsignificant. Older children ( $\geq 12$ years) were also significantly less hyperopic compared to younger children, and although the trend was similar to that reported by Maul et al in Chilean children ${ }^{(9)}$, whereas the shift we observed was about $0.15 \mathrm{D}$, in the Chilean study it was approximately $0.55 \mathrm{D}$.
Within the Latin American region, it is possible that child populations differ when it comes to refractive errors, and some of this difference may be due to ethnicity. Other potential factors that may influence can be the actual time spent at school, usually more in city settings when compared to their rural counterparts, and amount of time spent in outdoor activities.

There are some limitations to this study. First, we observed a large but consistent difference in spherical equivalent between autorefraction conducted under cycloplegia and autorefraction conducted under non-cycloplegic conditions. Although some researchers use non-cycloplegic autorefraction data, we preferred the use of cycloplegic data to avoid the effects of accommodation. In their study of 1443 Australian school children, Fotedar et al., noted that autorefraction without cycloplegia tended to substantially overestimate myopia and missed some cases of moderate hyperopia ${ }^{(20)}$ The mean SE difference between cycloplegia and non-cycloplegia in their study was 0.84 D, whereas it was larger in our study - about 1.10 D. In addition, we noted a small significant difference between SE data obtained from cycloplegic autorefraction versus retinoscopy. While retinoscopy has in the past been the gold standard of refractive error measurement, based on our knowledge of administering both techniques to children, it was felt that autorefraction would provide more consistent data compared to retinoscopy. However, this choice may have led to some systemic error that might have influenced the analysis. Second, there may have been some confounding effect in regard to location of the school (i.e., rural versus urban setting), although if this had been a large effect, we should have seen it in the mixed race group. Third, our samples were relatively small, which influenced the accuracy of our analysis. Finally, although the residents were well trained, we did not assess the intraclass correlation coefficient to determine if the data obtained by one resident were different to the other.

As a final note, it is worthy to mention that Paraguay has a rather unclear concept of ethnicity regarding the demographics of its population. In the $20^{\text {th }}$ century, it was widely accepted that up to $95 \%$ of the country was mixed race ${ }^{(21)}$. The most recent census in 2002 only counted for the indigenous population, and found that up to $1.7 \%$ is indigenous ${ }^{(22)}$. A more recent study analyzed the Paraguayan white population in the $21^{\text {st }}$ century based on the trends of European immigration in the last century and languages spoken at home, concluding that up to $20 \%$ of the country is of European (White) descent ${ }^{(21)}$. This is relevant to the study discussion since it was understood, while conducting the study, that the Mennonite population was the only White representation in Paraguay. It would be also interesting to include non-Mennonite White children, as well as Asian children in a more comprehensive study, considering that Asians make up 3.5\%(21) of the population (twice as much as the indigenous population). For now, this study is the first investigation of refractive error in $\mathrm{Pa}$ raguayan children that looks at ethnicity and further suggests that ethnicity might influence one's risk of developing refractive error.

\section{ACKNOWLEDGMENTS}

The authors would like to thank the Fundacion Vision, ORBIS, and the International Agency for the Prevention of Blindness for their financial support of this study and Kristen Eckert of Strategic Solutions for her assistance in editing the manuscript.

\section{REFERENCES}

1. Chen PC, Chang RJ, Lee DA, Wheeler NC. Prevalence of ocular disorders among 6- and 7-year-olds in Santa Monica, California. J Am Optom Assoc. 1996;67(6):358-65.

2. Kleinstein RN, Jones LA, Hullett $S$, Kwon $S$, Lee RJ, Friedman NE, Manny RE, Mutti DO, Yu JA, Zadnik K; Collaborative Longitudinal Evaluation of Ethnicity and Refractive Error Study Group. Refractive error and ethnicity in children. Arch Ophthalmol. 2003;121(8):1141-7.

3. Giordano L, Friedman DS, Repka MX, Katz J, Ibironke J, Hawes P, et al. Prevalence of refractive error among preschool children in an urban population: the Baltimore 
Pediatric Eye Disease Study. Ophthalmology. 2009;116(4):739-46. Comment in: Ophthalmology. 2010;117(6):1278-9.

4. Kleinstein RN, Sinnott LT, Jones-Jordan LA, Sims J, Zadnik K; for the Collaborative Longitudinal Evaluation of Ethnicity and Refractive Error Study Group. New cases of myopia in children. Arch Ophthalmol. 2012;130(10):1274-9.

5. Mavracanas TA, Mandalos A, Peios D, Golias V, Megalou K, Gregoriadou A, et al. Prevalence of myopia in a sample of Greek students. Acta Ophthalmol Scand. 2000; 78(6):656-9.

6. Lin LL, Shih YF, Tsai CB, Chen CJ, Lee LA, Hung PT, et al. Epidemiologic study of ocular refraction among schoolchildren in Taiwan in 1995. Optom Vis Sci. 1999;76(5):275-81.

7. Shih YF, Chiang TH, Lin LL. Lens thickness changes among schoolchildren in Taiwan. Invest Ophthalmol Vis Sci. 2009;50(6):2637-44.

8. Salomão SR, Cinoto RW, Berezovsky A, Mendieta L, Nakanami CR, Lipener C, et al. Prevalence and causes of visual impairment in low-middle income school children in Sao Paulo, Brazil. Invest Ophthalmol Vis Sci [Internet]. 2008[cited 2010 Jun 21]; 49(10):4308-13. Available from: http://www.iovs.org/content/49/10/4308.long

9. Maul E, Barroso S, Munoz SR, Sperduto RD, Ellwein LB. Refractive error study in children: results from La Florida, Chile. Am J Ophthalmol. 2000;129(4):445-54.

10. Castanon Holguin AM, Congdon N, Patel N, Ratcliffe A, Esteso P, Toledo Flores S, et al. Factors associated with spectacle-wear compliance in school-aged Mexican children. Invest Ophthalmol Vis Sci [Internet]. 2006[cited 2010 Jul 21];47:925-8. Available from: http://www.iovs.org/content/47/3/925.long

11. Morgan IG, Rose KA, Ellwein LB; Refractive Error Study in Children Survey Group. Is emmetropia the natural endpoint for human refractive development? An analysis of population-based data from the refractive error study in children (RESC). Arch Ophthalmol. 2010;88(8):877-84

12. Jones-Jordan LA, Sinnott LT, Manny RE, Cotter SA, Kleinstein RN, Mutti DO, Twelker JD, Zadnik K; Collaborative Longitudinal Evaluation of Ethnicity and Refractive Error (CLEERE) Study Group. Early childhood refractive error and parental history of myopia as predictors of myopia. Invest Ophthalmol Vis Sci [Internet]. 2010[cited 2012 Jun 23]; 51(1):115-21. Available from: http://www.iovs.org/content/51/1/115.long

13. Luo HD, Gazzard G, Liang Y, Shankar A, Tan DT, Saw SM. Defining myopia using refractive error and uncorrected logMAR visual acuity $>0.3$ from 1334 Singapore school children ages 7-9 years. Br J Ophthalmol. 2006;90(3):362-6.

14. Wu HM, Seet B, Yap EP, Saw SM, Lim TH, Chia KS. Does education explain ethnic differences in myopia prevalence? A population-based study of young adult males in Singapore. Optom Vis Sci. 2001;78(4):234-9.

15. Goldschmidt E, Lam CS, Opper S. The development of myopia in Hong Kong children. Acta Ophthalmol Scand. 2001;79(3):228-32.

16. Rose KA, Morgan IG, Smith W, Mitchell P. High heritability of myopia does not preclude rapid changes in prevalence. Clin Experiment Ophthalmol. 2002;30(3):168-72.

17. Saw SM. A synopsis of the prevalence rates and environmental risk factors for myopia. Clin Exp Optom. 2003;86(5):289-94.

18. Thorn F, Cruz AA, Machado AJ, Carvalho RA. Refractive status of indigenous people in the northwestern Amazon region of Brazil. Optom Vis Sci. 2005;82(2):267-72.

19. Vitale $S$, Ellwein $L$, Cotch MF, Ferris FL 3rd, Sperduto R. Prevalence of refractive error in the United States, 1999-2004. Arch Ophthalmol. 2008;126(8):1111-9.

20. Fotedar R, Rochtchina E, Morgan I, Wang JJ, Mitchell P. Rose KA. Necessity of cycloplegia for assessing refractive error in 12-year-old children: a population-based study. Am J Ophthalmol. 2007;144(2):307-9.

21. Fernández FL. Composición étnica de las tres areas culturales del continente Americano al comienzo del siglo XXI. Convergencia [Internet]. 2005[cited 2010 Jun 21]; 38:185-232. Available from: http://convergencia.uaemex.mx/rev38/38pdf/LIZCANO. pdf

22. Paraguay. Dirección general de estadísticas, encuestas, y censos (DGEC). II Censo Nacional a de Población y Viviendas 2002 [Internet]. Paraguay: DGEC; 2002. [cied 2012 Dec 13]. Available from: http://www.dgeec.gov.py/publicaciones/Biblioteca/ censo_indigena/capitulo\%201.pdf 